2

\title{
The responsibility to protect: A forward-looking agenda
}

\author{
Ramesh Thakur
}

One of the most dramatic normative developments of our time relates to the use of military force to protect human beings by finessing the tension between state sovereignty and international intervention through a redefinition of "sovereignty" and "humanitarian intervention" as the "responsibility to protect", the title of the 2001 report by the International Commission on Intervention and State Sovereignty (ICISS). ${ }^{1}$ Traditional warfare is the use of force by rival armies of enemy states fighting over a clash of interests: us against them. Collective security rests on the use of force by the international community of states to defeat or punish an aggressor from within the community, whoever that may be: all against one. Peacekeeping involves the insertion of neutral and lightly armed thirdparty soldiers as a physical buffer between enemy combatants who have agreed to a ceasefire: us between formerly fighting enemies.

The "responsibility to protect" redefines sovereignty as responsibility and locates the responsibility in the first instance with the state. If, but only if, the state is unwilling or unable to honour the responsibility, or is itself the perpetrator of atrocities, then the residual responsibility to protect victims of atrocity crimes shifts to the international community of states, acting ideally through the United Nations Security Council. Thus, the "responsibility to protect" refers to the use of military force by outsiders for the protection of victims of mass atrocities: us against perpetrators, as protectors of victims of mass atrocities.

When UN Secretary-General Kofi Annan issued his famous "challenge of humanitarian intervention" in September 1999, he provoked a furious

Blood and borders: The responsibility to protect and the problem of the kin-state, Kemp, Popovski and Thakur (eds), United Nations University Press, 2011, ISBN 987-92-808-1196-4 
backlash from many countries around the world. Yet, a mere six years later, the R2P norm was endorsed by the world leaders gathered at the United Nations. Annan called it one of his "most precious of all" achievements. ${ }^{2}$ The idea has taken such rapid and seemingly firm hold as to have its own distinctive acronym, R2P; its own new journal, with the inaugural issue published in $2009 ;{ }^{3}$ and even T-shirts for university students. ${ }^{4}$ Sovereignty no longer implies the licence to kill: "We are all atrocitarians now - but so far only in words, and not yet in deeds." 5

Therein lies the rub, and that is the subject of this chapter. I will first situate R2P in the context of the so-called "challenge of humanitarian intervention" in the 1990s and trace the displacement of the challenge with the responsibility to protect and its adoption by world leaders in 2005 , then bring it up to date with the report of the UN SecretaryGeneral in January 2009, before outlining, as the main task of this chapter, the unfinished agenda of operationalizing the norm.

\section{From the 1990s challenge of humanitarian intervention to the 2005 World Summit}

Created from the ashes of the Second World War, with the allies determined to prevent a repeat of Adolf Hitler's abominations, the United Nations for most of its existence has focused far more on external aggression than on internal mass killings. Yet Nazi Germany was guilty of both. Unlike aggression against other countries, the systematic and large-scale extermination of Jews was a new horror. In this new century, the world organization is at long last elevating the doctrine of preventing mass atrocities against people to the same level of collective responsibility as preventing and repelling armed aggression against states.

The attributes and exercise of sovereignty have softened significantly since 1945 . The use of force, both domestically and internationally, was an acknowledged attribute of state sovereignty, and war itself was an accepted institution of the Westphalian system with distinctive rules, etiquette, norms and stable patterns of practices to govern armed conflicts. ${ }^{6}$ In that quasi-Hobbesian world barely removed from the state of nature, the main protection against aggression was countervailing power, which increased both the cost of victory and the risk of failure. Since 1945, the United Nations has spawned a corpus of law to stigmatize state use of force and create a robust norm against it. Today there exist numerous and significant restrictions on the authority of states to use force either domestically or internationally.

A further challenge to the Westphalian order came with the adoption of new standards of conduct for states in the protection and advancement 
of international human rights. Individuals became subjects of international law as bearers of duties and holders of rights under a growing corpus of human rights and international humanitarian law treaties and conventions.

Third, over time, the chief threats to international security have come from violent eruptions of crises within states, including civil wars, while the goals of promoting human rights and democratic governance, protecting civilian victims of humanitarian atrocities and punishing governmental perpetrators of mass crimes have become more important. Moreover, noncombatants dying from conflict-related starvation and disease now vastly outnumber troops killed directly in warfare, by a ratio of up to 9:1. The "maintenance of international peace and security", for which primary responsibility is vested in the Security Council, in practice translates into the protection of civilians. In a number of cases in the 1990s, the Security Council's imprimatur covered the use of force with the primary goal of humanitarian protection and assistance. ${ }^{7}$

Fourth, the proliferation of complex humanitarian emergencies after the end of the Cold War, and the inappropriateness of the classical tenets of UN peacekeeping for dealing with them, ${ }^{8}$ highlighted the inherent tension between the neutrality and impartiality of traditional peacekeeping and the partial consequences of peace enforcement. The Brahimi Report confronted the dilemma squarely and concluded that political neutrality has often degenerated into military timidity and the abdication of the duty to protect civilians. Impartiality should not translate into complicity with evil. ${ }^{9}$

Fifth, it has become commonplace to note that, under the impact of globalization, political, social, commercial-economic, environmental and technological influences cross borders without passports. The total range of cross-border flows and activities has increased while the proportion subject to control and regulation by governments has diminished. National frontiers are becoming less relevant in determining the flow of ideas, information, goods, services, capital, labour and technology. The speed of modern communications makes borders increasingly permeable, while the volume of cross-border flows threatens to overwhelm the capacity of states to manage them.

The cumulative effect of these changes has posed significant conceptual, policy and operational challenges to the notion of state sovereignty, which is considerably less sacrosanct today than in 1945. ICISS responded to a series of military-civilian interactions in humanitarian crises that confronted directly the egregious non-reactions by the Security Council, as epitomized in particular by the Rwanda genocide in 1994 and the intervention in Kosovo in 1999 by the North Atlantic Treaty Organization (NATO). In both cases, many human rights advocates and humanitarian agencies supported the military protection of civilians whose lives were 
threatened, thereby exposing the glaring normative gap for collective action more clearly than in the past. If the United Nations was going to be relevant, it had to engineer a basis for international involvement in the ugly civil wars that produced such conscience-shocking suffering.

Norms neither arise nor are converted into laws and regimes by some mysterious process. They require identifiable agents. The crucial actors promoting and shepherding R2P through the maze of UN politics can be broken down into norm entrepreneurs, champions and brokers.

As a norm entrepreneur, the UN Secretary-General is a unique international actor with distinctive characteristics and bases of authority and influence, albeit with limitations. ${ }^{10}$ Annan was driven both by character and by his experience of being in charge of peacekeeping at the time of the Rwanda and Srebrenica massacres in 1994 and 1995. It helped also that, as the only UN insider to have held the organization's top job, he had an unmatched grasp of UN politics. ${ }^{11}$ The other two norm entrepreneurs crucial to the R2P story are Lloyd Axworthy and Gareth Evans, the activist foreign ministers of Canada and Australia who respectively set up and co-chaired ICISS.

R2P's state champion from start to finish was Canada, a country strongly committed to UN-centred multilateralism, with a history of close engagement with the world organization, political credibility in both North and South and a proud tradition of successful global initiatives. There were several other like-minded countries such as Norway and Switzerland, as well as major foundations such as MacArthur and other actors such as the International Committee of the Red Cross, which worked closely with ICISS in supportive advocacy.

The norm broker was ICISS. Its mandate was to reconcile the tension between "intervention" and "state sovereignty" and to find common ground for military intervention to support humanitarian objectives. Humanitarian imperatives and principles of sovereignty are reconciled through "the responsibility to protect", a paraphrase of "sovereignty as responsibility" with some conceptual and enormous political consequences.

The ICISS Report was published with exceptionally bad timing in December 2001. It suffered from attention deficit disorder because the world was preoccupied with "9/11" and its aftermath. ${ }^{12}$ The subsequent invasion of Iraq and the ousting of Saddam Hussein by a US-led coalition acting without UN authorization had a doubly damaging effect. First, as tensions mounted in 2002-2003, few had the time to focus on R2P. Second, as the weapons of mass destruction justification for the war fell apart and claims of close links between Saddam's regime and al-Qaeda also proved spurious, the coalition of the willing - Australia, the United Kingdom and the United States as the three main belligerent states - began retroact- 
ively to use the language of humanitarian intervention and $\mathrm{R} 2 \mathrm{P}$ as the main plank of justification for their actions in Iraq.

Some of the ICISS Commissioners argued strenuously in the public debate that Iraq would not have met the R2P test for intervention. ${ }^{13}$ Co-chair Gareth Evans, Commissioner Ramesh Thakur and Research Director Thomas Weiss spoke and wrote extensively in the years following the publication of the report to multiple audiences: policy (intergovernmental and government officials), scholarly and civil society. ${ }^{14}$ The Canadian government organized an extensive series of consultations with governments, regional organizations and civil society forums, typically using the two co-chairs, as well as Thakur and Weiss (and some other ICISS members within their regions), to help promote the report. As the message resonated, many civil society organizations began advocacy and dissemination work on their own as well.

The Secretary-General's High-Level Panel on Threats, Challenges and Change, which included Evans, reaffirmed the importance of the terminological change from "humanitarian intervention" to "the responsibility to protect". It explicitly endorsed the ICISS argument that "the issue is not 'the right to intervene' of any State, but the 'responsibility to protect' of every State". ${ }^{15}$ It proposed five criteria of legitimacy: seriousness of threat, proper purpose, last resort, proportional means, and balance of consequences. ${ }^{16}$ China's formal paper on UN reforms noted that "[e]ach state shoulders the primary responsibility to protect its own population.... When a massive humanitarian crisis occurs, it is the legitimate concern of the international community to ease and defuse the crisis." 17 In the United States, the Gingrich-Mitchell Task Force too endorsed the responsibility to protect. ${ }^{18}$ In his own report before the World Summit, Annan made an explicit reference to ICISS and R2P as well as to the High-Level Panel, endorsed the legitimacy criteria and urged the Security Council to adopt a Resolution "setting out these principles and expressing its intention to be guided by them" when authorizing the use of force. ${ }^{19}$

R2P was one of the few substantive items to survive the negotiations at the World Summit in New York in September 2005. Some R2P enthusiasts criticized the summit's emphasis on the state and the requirement for coercive measures to be authorized by the Security Council as constituting "R2P lite", while others thought that paragraphs 138-139 of the World Summit Outcome document were wordier and woollier than the ICISS version. ${ }^{20}$ The already high ICISS bar was raised again with the emphasis on states "manifestly failing" in their responsibility to protect. At the same time, the circumstances justifying international intervention were narrowed down from large-scale killings and ethnic cleansing to the four specified cases of genocide, war crimes, crimes against humanity and 
ethnic cleansing - and nothing else. And the emphasis on atrocities being apprehended, not necessarily actually occurring, was lost in translation.

This does not diminish the importance of the achievement. The concept was given its own subsection title. The document marks a clear, unambiguous acceptance by all UN members of individual state responsibility to protect populations from genocide, war crimes, ethnic cleansing and crimes against humanity. Member states further declared that they "are prepared to take collective action, in timely and decisive manner, through the Security Council ... and in cooperation with relevant regional organizations as appropriate, should peaceful means be inadequate and national authorities are manifestly failing to protect their populations". ${ }^{21}$ However, the legitimacy criteria - which would simultaneously make the Security Council more responsive to outbreaks of humanitarian atrocities than hitherto and make it more difficult for individual states or ad hoc "coalitions of the willing" to appropriate the language of humanitarianism for geopolitical and unilateral interventions - were dropped. ${ }^{22}$

\section{The Report of the UN Secretary-General, 2009}

Ban Ki-moon succeeded Kofi Annan as UN Secretary-General a little over a year after the 2005 World Summit's endorsement of R2P. Ban has not been shy of adopting R2P as his own cause, confident enough of his own worth not to worry that he will merely be advancing his predecessor's legacy. (There is a lesson in this for the Harper government in Ottawa. Instead of embracing R2P proudly and celebrating it as a Canadian success, it has kept its distance because it was the Liberal government's initiative.) His task was the harder for so many countries seeing him as Washington's choice (and in particular the choice of UN-sceptical US Ambassador John Bolton). The problem was compounded by choosing an American, Professor Edward C. Luck, as his Special Adviser with a focus on R2P, one with little professional background on the subject.

Ed Luck did come to the post with several key assets and advantages: a deep knowledge of UN-US relations; intimate familiarity with the UN system and structures, including the institutional bottlenecks to reform; the ability to think, speak and write clearly and succinctly; and the confidence of Ban. Despite ceding ground to critics and dropping R2P from Luck's title, Ban remained focused on the issue and fully supported Luck's efforts to talk through the agenda with the various UN constituencies. In sharp contrast to Bolton's suspicion of the principle, US Ambassador Susan Rice endorsed the norm and, in a closed door session of the Security Council on 29 January 2009, affirmed that the new Obama administration took the responsibility to protect very seriously. 
Drawing on Luck's wide-ranging consultations and reflections, in January 2009 Ban published his report on implementing R2P. ${ }^{23}$ It rightly takes as its key point of departure not the original 2001 ICISS Report but the relevant clauses from the 2005 Outcome document. It clarifies and elaborates some things, for example the fact that because force is the last resort does not mean we have to go through a sequential or graduated set of responses before responding robustly to an urgent crisis (para. 50). But in practice, as Washington discovered in 2003, it will be exceedingly difficult to get UN agreement to the use of force other than as the last resort, after all other options have been seen to be tried, exhausted and failed. Ban's report does not add much to the substance of what was said in 2001, and therefore could have been shorter instead of exceeding the length guidelines instituted by Annan for such reports. But it does flesh out in greater and clearer detail many of the ideas of the 2001 report. It notes explicitly that all peoples inside a state's territorial jurisdiction, not just citizens, must be protected by a state (para. 11.a). Following both the Brahimi and ICISS reports and the 2005 Outcome document, it reiterates the requirement for early warning capacity (annex) - without explaining how the politics of the UN community will be overcome to achieve this.

Moreover, it is a good read, eschewing bureaucratese. It notes "the brutal legacy of the twentieth century" that "speaks bitterly and graphically of the profound failure of individual States to live up to their most basic and compelling responsibilities, as well as the collective inadequacies of international institutions" (para. 5). It asks if in the new century we cannot find the will and the capacity to do better. It notes "clarity, simplicity, and lack of qualifications or caveats" in the Outcome document's adoption of R2P in 2005 (para. 13). And it points out that "the choice need not be a stark one between doing nothing or using force" (para. 11.c).

Ban's report is effective and clever in repackaging R2P in the language of three pillars: the state's own responsibility to protect all peoples on its territory; international assistance to help build a state's capacity to deliver on its responsibility; and the international responsibility to protect. If the metaphor helps to garner more widespread support, all praise to Ban and his team.

Still, the report goes over the top in elaborating on the metaphor by insisting that the "edifice" of R2P will tilt, totter and collapse unless all three pillars are of equal height and strength (para. 12). This is simply not true. The most important element - the weightiest pillar - has to be the state's own responsibility. And the most critical is the international community's response to fresh outbreaks of mass atrocity crimes. Although the resistance of people to abbreviating the norm into $\mathrm{R} 2 \mathrm{P}$ is understandable, reformulating R2P as "RtoP" as a distinguishing contribution 
(Summary and para. 2) is petty and just plain silly. It confuses rather than helps and is also less elegant.

Mercifully, and contrary to what many of us feared, Ban's report does not retreat from the necessity for outside military action in some circumstances. But it does dilute what was the central defining feature of R2P. The ICISS was called into existence to deal with the problem of brutal leaders killing large numbers of their own people. It built on the landmark Brahimi Report of 2000, which noted that the United Nations cannot be neutral between perpetrators and victims of large-scale violence. We are all happy to assist the good guys build state capacity. The challenge is what to do with the bad guys, those intent on grave harm who use sovereignty as a licence to kill with impunity.

R2P's added value is that it crystallized an emerging new norm of using international force to prevent and halt mass killings by reconceptualizing sovereignty as responsibility. It aims to convert a shocked international conscience into timely and decisive collective action. This requires urgent clarification with respect to both when it should kick in as an international responsibility and when not; who makes these decisions; and on what basis. Do R2P operations require their own distinctive guidelines on the use of force? How and where can we institute systematic risk assessments and early warning indicators to alert us to developing R2P-type crises? How do we build international capacity and will to protect at-risk populations when state authorities are complicit through either incapacity or, more culpably, direct complicity?

On these key issues, we are no further ahead today: we seem to be recreating the 2005 consensus instead of operationalizing and implementing the agreed collective responsibility. The use of force by the United $\mathrm{Na}$ tions against a state's consent will always be controversial and contested. That is no reason to hand over control of the pace, direction and substance of the agenda of our shared, solemn responsibility to the R2P sceptics. $^{24}$

\section{From words to deeds, principle to practice: An unfinished journey}

$\mathrm{R} 2 \mathrm{P}$ is a call to action on prevention, intervention and post-conflict reconstruction. There is always a danger with radical advances that commitments at grand summits will suffer many a slip after the champagne flutes are stored. R2P is not just a slogan. Failure to act will make a mockery of the noble sentiments. The implementation and compliance gap is especially distasteful when mass murder and ethnic cleansing are the result of sitting on the sidelines. 
The 2005 Outcome document notwithstanding, some national diplomats insist that the heads of state and government rejected R2P in $2005 .{ }^{25}$ The first danger thus is that of rollback: a shamefaced edging back from the agreed norm of 2005, a form of buyer's remorse. The need exists for continued advocacy and activism by civil society and for concerned governments to remain steadfast and hold all governments' feet to the fire of individual and collective responsibility to protect at-risk populations. After a lecture in Colombo, Sri Lanka, Gareth Evans armed with R2P in 2007 was flatteringly compared to the coming of Christopher Columbus in 1492 and Vasco da Gama in 1498 armed with the Bible and the sword. ${ }^{26}$ One newspaper reported on "crackpot ideas" such as R2P that have been "dismissed in academic and political circles as the latest "neoimperialist' tactic of the big powers to intervene in the affairs of small nations". ${ }^{27}$

Many regimes that fear the searchlight of international attention being shone on their misdeeds will try to chip away at the norm until only a façade remains. The advocates of R2P cannot allow them to succeed. Better that the serially abusive regimes live with this fear of international intervention than that their people fear being visited by death and disappearance squads. Of course, members of such regimes could remove the cause of such fear by working, by themselves (Pillar I) or in concert with international friends (Pillar II), to remove the causes and prevent a crisis from arising.

A second, opposite danger of rollback lies with the aggressive humanitarian warriors who gave "humanitarian intervention" such a bad name in the first place. Iraq is the best example of why the authors and promoters of R2P fear certain "friends" as much as opponents. Developing countries' histories and their peoples' collective memories are full of past examples of trauma and suffering rooted in the white man's burden. The weight of that historical baggage is simply too strong to sustain the continued use of the language of humanitarian intervention.

Another danger from over-enthusiastic supporters is misuse of the concept in non-R2P contexts. A group of retired NATO generals, including an ICISS Commissioner, for example, used it to justify the first use of nuclear weapons to prevent nuclear proliferation. ${ }^{28}$ Others have used the label to refer to action to halt the spread of HIV/AIDS or to protect indigenous populations from climate change.

An admittedly tougher case arose in 2008 with Myanmar's deadly Cyclone Nargis, when principles, politics and practicality nonetheless converged in counselling caution in invoking R2P. There is no morally significant difference between large numbers of people being killed by soldiers firing into crowds and the government blocking help being delivered to the victims of natural disasters. 
Conceptually, the shift from the crime of mass killings by acts of commission such as shooting people to acts of omission such as preventing them from getting food and medical attention is a difference of degree, not of kind.

Legally, the four categories where R2P apply are genocide, war crimes, ethnic cleansing and crimes against humanity. The original ICISS Report (para. 4.20) explicitly included "overwhelming natural or environmental catastrophes" causing significant loss of life as triggering R2P if the state was unable or unwilling to cope or rebuffed assistance. This was dropped by 2005 . But "crimes against humanity" were included and could perhaps apply to the Burmese generals' actions in blocking outside aid.

Politically, however, one cannot ignore the significance of the exclusion of natural and environmental disasters in 2005. Clearly, the normative consensus on the new global norm did not extend beyond the acts of commission of atrocity crimes by delinquent governments. To attempt to reintroduce it by the back door today would strengthen suspicion of Western motivations and reinforce cynicism of Western tactics. The United Nations must base its decisions on the collectively expressed will of its member states, not on that of an independent commission or individual member states. Unlike previous decades, the new unity of the global South, led by Brazil, China, India and South Africa, is based on a position of strength, not weakness. The West can no longer set or control the agenda of international policy discourse and action.

Practically, there is no humanitarian crisis so grave that it cannot be made worse by military intervention. Unappealing as they might be, the generals are in effective control of Myanmar. The only way to get aid quickly to where it is most needed is with the cooperation of the authorities. If they refuse, the notion of fighting one's way through to the victims is ludicrous. The militarily overstretched Western powers have neither the capacity nor the will to start another war in the jungles of Southeast Asia. If foreign soldiers are involved, it does not take long for a war of liberation or humanitarian assistance to morph into a war of foreign occupation in the eyes of the local populace.

There is also the question of which is more damaging to R2P in the longer term: invoking or ignoring it in the context of natural disasters such as Cyclone Nargis. If the invocation does not help in the immediate emergency, this may indeed cause even more determined opposition and intensify the backlash against R2P; then the painfully forged consensus on the $\mathrm{R} 2 \mathrm{P}$ norm will fracture without any material help being provided to the displaced and distressed. That is, help will be less forthcoming to the next group of victims of large-scale killings. The correct equation thus is that invoking R2P in Myanmar would have endangered lives elsewhere in the future, without saving any and possibly even delaying help for the 
Nargis victims in 2008. Feeling good about one's own moral superiority by accusing others of privileging a norm over saving lives is a peculiar form of self-indulgence that perpetuates the killing fields without alleviating anyone's suffering.

Diplomatic pressure was better exerted on the basis of humanitarian principles enshrined in a number of UN General Assembly resolutions than on the coercive language of military intervention for which no one had the stomach and few had the capacity. These include the Guiding Principles for humanitarian assistance of Resolution 46/182 in 1991, the 2005 World Summit Outcome document, Resolution A/RES/61/134 of December 2006, and, most recently, Resolution A/RES/62/93 of December 2007. There are also the agreed norms and guiding principles in relation to internally displaced persons. All of these recognize and reaffirm the norm of state sovereignty and the principle of state consent. But they also call on the afflicted states to facilitate the work of humanitarian actors providing relief and assistance and to provide safe and unhindered access to humanitarian personnel. In the end, Secretary-General Ban's use of the bully pulpit, good offices and personal on-the-spot diplomacy did make a difference that may not have been enough to satisfy the habitual UN critics but was nonetheless crucial in helping many in distress through relaxing some curbs on international relief efforts.

A related danger is seeking remedy in R2P when better or more appropriate tools and instruments are available for dealing with the crisis at hand. A good example of this occurred in 2009 when Israel launched a massive offensive in Hamas-ruled Gaza, putatively in response to rocket attacks from Gaza against civilian targets in Israel. There were issues of international and UN Charter law involved: the well-established rights to self-defence against armed attack and to resist foreign occupation; the validity of these justifications for the resort to violence by Israel and Palestinians; and the limits to the exercise of these rights. There were issues of international humanitarian law: regardless of whether or not the use of force itself is lawful, the conduct of hostilities is still governed by the Geneva laws with respect to proportionality, necessity and distinction between combatants and civilians. There were charges and counter-charges, including by responsible UN officials and special rapporteurs, ${ }^{29}$ of the possible commission of war crimes. In the midst of all this, the invocation of $\mathrm{R} 2 \mathrm{P}$ did not seem to be the most pressing or most relevant contribution to the solution. At the same time, the debate over Gaza also raised the further question of occupying powers' responsibility to protect all peoples living under their occupation, be they Palestinians or Iraqis or Afghans.

To return to the point about Ban's 2009 report not providing a sharp enough clarification of the use of force to save lives, the original ICISS 
report could rightly be said to be the root of this problem. For it failed to make a forceful distinction between state incapacity, on the one hand, and state complicity through unwillingness or perpetration, on the other hand. A good example of the latter would be the killing of up to 2,000 Muslims in the state of Gujarat in India in 2002 under the baleful influence of a Hindutva government in the province. The distinction is fine in principle but enormously consequential for policy.

As noted earlier, external military intervention to protect civilians inside sovereign borders without the consent of the state concerned differs from traditional warfare, collective security and peace operations. The protection of victims from mass atrocities requires different guidelines and rules of engagement as well as different relationships to civil authorities and humanitarian actors. These differences need to be identified, articulated and incorporated into officer training manuals and courses. ${ }^{30}$ For example, recalling the tragedy of Rwanda in 1994: how does a UN peace operation, sent to supervise a peace agreement and process, recast its task on the fly to prevent an unfolding genocide?

Operationalizing $\mathrm{R} 2 \mathrm{P}$ with respect to the protection agenda in the field will mean adopting a bottom-up approach that brings together the humanitarian actors on the ground in conflict zones. ${ }^{31}$ Each context requires its own specific protection actions against threats to the people at risk there. The United Nations can provide the normative mandate at the global level for their protection and the forces necessary for intervention if need be. The action to prevent and rebuild has to be undertaken by UN agencies acting collaboratively with local civil society actors, nongovernmental organizations and representatives of the Red Cross and Red Crescent movement. They can be brought together in a distinct protection cluster to assess needs and priorities for each vulnerable group requiring protection and identifying, in advance, the custom-tailored responses for prevention and rebuilding.

At the same time, opponents have a point in cautioning about the moral hazard that would result from over-enthusiastic recourse to international intervention. It can create perverse incentives for rebels and dissidents to provoke state retaliation to armed challenges. This was recognized by Kofi Annan just one year after his "challenge of humanitarian intervention". In his Millennium Report, he conceded that his call for a debate on the challenge of humanitarian intervention had led to fears that the concept "might encourage secessionist movements deliberately to provoke governments into committing gross violations of human rights in order to trigger external interventions that would aid their cause". ${ }^{32}$ This needs further research as well. ${ }^{33}$

So too does the question of whether groups who constitute a minority in one country and are targeted for killings or ethnic cleansing based on 
their group identity are owed any responsibility by their kin-state: China vis-à-vis overseas Chinese, say in Indonesia, or India vis-à-vis ethnic Indians in Fiji ${ }^{34}$ or Tamil Hindus in Sri Lanka, or Pakistan vis-à-vis Muslims in India, or Russia vis-à-vis Russians in the Baltic states, or Albania vis-àvis Albanians around the Balkans, or the West vis-à-vis the whites in Zimbabwe. This, of course, is the subject of detailed exploration - historical, philosophical, normative and legal - in this volume. Inter-ethnic conflict and genocide have demonstrated the dangers of failing to protect people targeted by their fellow citizens. The general international opinion around the world in 2008 was that Russia invoked R2P to camouflage highly traditional geopolitical calculations in launching military action against Georgia in defence of its interests in South Ossetia. ${ }^{35}$ But unilateral intervention by a kin-state can lead to conflict within and between states. This presents a dilemma: although the world cannot stand by when minority rights are being trampled, the protection of national minorities should not be used as an excuse to violate state sovereignty. Therefore, how can R2P be applied to the protection of persons belonging to national minorities? Whose responsibility is it to protect such persons? A sensible answer might come from the formula that France uses to describe its relationship with Quebec in Canada: ni ingérence ni indifférence (neither interference/intervention nor indifference).

Of course, the question of protecting members of the kin group in neighbouring or distant locations outside the territorial borders is conceptually linked also to the question of protecting one's citizens who come under attack overseas. Thus the United States invaded Grenada ostensibly with the goal of protecting US citizens, and Israel has sometimes exercised the right to use its military forces to rescue its nationals from foreign trouble spots and dangers.

As the Burmese, South Ossetian and Gaza conundrums show, to date our responses have typically been ad hoc and reactive, rather than consolidated, comprehensive and systematic. We need a paradigm shift from a culture of reaction to one of prevention and rebuilding.

Yet another item on the research agenda would be to examine past iconic examples of horrific atrocities and genocidal killings in twentiethcentury history, including the Holocaust, Bangladesh, Cambodia, Rwanda and the Balkans. Conversely, there are some iconic cases of "bad" interventions, such as that to remove the Marxist Allende regime in Chile, that could also be studied with respect to what, if any, difference R2P would or might have made. This would apply especially if legitimacy criteria could be approved by consensus.

This extensive research agenda will help to build a caseload of R2Ptype situations as a guide to future deliberations, evidence-based analyses and robust action. Civil society continues advocating on this issue. For 
example, a sub-unit within the World Federalist Movement's office in New York has been engaged in support of R2P for several years. Recognizing that the global endorsement of the norm in 2005 was but the prelude to translating it into timely action to prevent crises and stop atrocities, the Global Centre for the Responsibility to Protect (GCR2P), based at the Ralph Bunche Institute for International Studies at the Graduate Center of the City University of New York (CUNY), was launched in February 2008 at the United Nations. Ban Ki-moon welcomed the Global Centre's establishment as "an effective advocate in the struggle to prevent the world's most heinous mass crimes". ${ }^{36}$ Supported by several governments, foundations and private donors, it will generate research, conduct high-level advocacy and facilitate the activities of those working to advance the R2P agenda.

\section{Conclusion}

"I saw the crisis in the R2P prism with a Kenyan government unable to contain the situation or protect its people.... I knew that if the international community did not intervene, things would go hopelessly wrong. The problem is when we say 'intervention', people think military, when in fact that's a last resort. Kenya is a successful example of R2P at work." (Kofi Annan ${ }^{37}$ )

$\mathrm{R} 2 \mathrm{P}$ is much more fundamentally about building state capacity than undermining state sovereignty. The scope for military intervention under its provenance is narrow and tight. The instruments for implementing its prevention and reconstruction responsibilities on a broad front are plentiful. When post-election violence broke out in Kenya in December 2007-January 2008, Francis Deng urged the authorities to meet their responsibility to protect the civilian population. ${ }^{38}$ Archbishop Emeritus Desmond Tutu interpreted the African and global reaction to the Kenyan violence as "action on a fundamental principle - the Responsibility to Protect". ${ }^{39}$ Called in to mediate, Annan too saw the crisis in R2P terms. His successful mediation to produce a power-sharing deal is the only positive R2P marker to date.

One possible means of entrenching the norm in public and policy discourse would be to cite paragraphs 138 and 139 of the Outcome document in the preambular paragraphs of all relevant Security Council resolutions creating or renewing UN peace operations, and the operative paragraphs could contain the protection of civilians in armed conflict as part of the mandate of UN missions. This could help to generate the sort of norm entrapment that is familiar from the human rights literature. That is, every time that a state protests that R2P is not applicable to it, 
that critics have misunderstood the facts or not taken due account of the context, it acknowledges and reinforces the global norm even while questioning its applicability in the specific case to hand. Similarly, much as imitation is the sincerest form of flattery, Russia's invocation of the R2P norm in its 2008 invasion of Georgia was a tribute to the moral power of R2P.

History proves that, sovereignty and the norm of non-intervention notwithstanding, regional and global powers have intervened, repeatedly, in the affairs of weaker states. ${ }^{40}$ After the end of the Cold War, the Security Council experienced a spurt of enforcement activity within civil wars to provide international relief and assistance to victims of large-scale atrocities from perpetrator or failing states. From Liberia and the Balkans to Somalia, Kosovo and East Timor, conscience-shocking humanitarian catastrophes were explicitly recognized as threats to international peace and security requiring and justifying forceful responses. When the Security Council was unable to act owing to lack of enforcement capacity, it subcontracted the military operation to UN-authorized coalitions. And if it proved unwilling to act, sometimes groups of countries forged coalitions of the willing to act anyway, even without Security Council authorization.

$\mathrm{R} 2 \mathrm{P}$ offers developing countries better protection through agreed and negotiated-in-advance rules and roadmaps for when outside intervention is justified and how it may be done under UN authority rather than unilaterally. It will thus lead to the "Gulliverization" of the use of force by major global and regional powers, tying it with numerous threads of global norms and rules. Absent R2P, they have relatively more freedom, not less, to do what they want. R2P is rooted in human solidarity, not in exceptionalism of the virtuous West against the evil rest. And, contrary to what many developing country governments might claim, it is rooted as firmly in their own indigenous values and traditions as in abstract notions of sovereignty derived from European thought and practice. Many traditional Asian cultures stress the symbiotic link between duties owed by kings to subjects and loyalty of citizens to sovereigns, a point made by civil society representatives who accordingly conclude that, far from abridging sovereignty, R2P enhances it. ${ }^{41}$ Even in a modern context, India's constitution imposes R2P-type responsibility on governments in its chapters on fundamental rights and the directive principles of state policy. ${ }^{42}$

By the same token, however, Westerners need to recognize and accommodate developing country sensitivities. The crisis over "humanitarian intervention" arose because too many developing countries concluded that a newly aggressive West, intoxicated by its triumph in the Cold War, was trying to ram its values, priorities and agenda down their throats. Even today, differences within both camps notwithstanding, the global North/ 
South divide is the most significant point of contention for "the international community". ${ }^{43}$ With regard to the use of force, for example, advocates of the right to non-UN-authorized humanitarian intervention in essence insisted that the internal use of force by the rest would be held up to international scrutiny, but the international use of force by the West could be free of UN scrutiny. For developing countries, the United Nations was a key instrument for the protection of vulnerable nations from predatory major powers; for many Westerners, it was acting to thwart forceful action to forestall or stop the killing of vulnerable people.

ICISS engaged in an extensive outreach exercise involving a crosssection of governmental and civil society representatives in every continent, in which it listened to and often incorporated ideas expressed by others instead of simply talking to them. ${ }^{44}$ The overwhelming dominance of Westerners in global intellectual discourse and civil society influence is an unfortunate fact of life. A major reason for the failure of the 2005 Outcome document to include a single reference to the nuclear weapons challenge was the backlash against the unilateral reinterpretation by the five NPT-licit nuclear powers of the Nuclear Non-Proliferation Treaty that it was solely about non-proliferation obligations by the rest instead of a package bargain between non-proliferation and disarmament obligations. In a Security Council debate on the protection of civilians in armed conflict on 4 December 2006, Chinese ambassador Liu Zhemin warned that the 2005 Outcome document was "a very cautious representation of the responsibility to protect populations from genocide, war crimes, ethnic cleansing and crimes against humanity ... it is not appropriate to expand, wilfully to interpret or even abuse this concept". ${ }^{45}$ Yet that is precisely what was suggested in 2008 in the context of Cyclone Nargis and more recently by the London-based One World Trust. ${ }^{46}$ Ban is surely right in warning that "it would be counterproductive, and possibly even destructive, to try to revisit the negotiations that led to the provisions of paragraphs 138 and 139 of the Summit Outcome". ${ }^{47}$

\section{Notes}

1. International Commission on Intervention and State Sovereignty, The Responsibility to Protect (Ottawa: International Development Research Centre, 2001).

2. Kofi Annan, "A Progress Report on UN Renewal", Speech to the UN Association UK, London, 31 January 2006, New World, April-June 2006, p. 8.

3. Global Responsibility to Protect (GR2P).

4. At the 2009 symposium entitled "Responsibility to Protect" of the Harvard Human Rights Journal, Cambridge, MA, 20 February 2009.

5. Gary J. Bass, Freedom's Battle: The Origins of Humanitarian Intervention (New York: Knopf, 2008), p. 382 
6. See Kalevi J. Holsti, War, the State, and the State of War (Cambridge: Cambridge University Press, 1996).

7. See Brian D. Lepard, Rethinking Humanitarian Intervention (University Park: Pennsylvania State University Press, 2002), pp. 7-23.

8. See Ramesh Thakur and Carlyle A. Thayer, eds, A Crisis of Expectations: UN Peacekeeping in the 1990s (Boulder, CO: Westview, 1995).

9. Report of the Panel on United Nations Peace Operations, UN Doc. A/55/305-S/2000/809, 21 August 2000.

10. See Ramesh Thakur, The United Nations, Peace and Security: From Collective Security to the Responsibility to Protect (Cambridge: Cambridge University Press, 2006), ch. 14; and Simon Chesterman, ed., Secretary or General? The UN Secretary-General in World Politics (Cambridge: Cambridge University Press, 2007).

11. For a discussion of UN policy-making, see Ramesh Thakur and Thomas G. Weiss "United Nations 'Policy': An Argument with Three Illustrations", International Studies Perspectives 10:1 (2009), pp. 18-35.

922 e2e8b 7 c30f3204af52f6aa 63 fdcl 6e

12. See Ramesh Thakur, War in Our Time: Reflections on Iraq, Terrorism and Weapons of ebrary Mass Destruction (Tokyo: United Nations University Press, 2007).

13. Gareth Evans, "Humanity Did Not Justify This War", Financial Times, 15 May 2003; Ramesh Thakur, "Chrétien Was Right: It's Time to Redefine a 'Just War'”, Globe and Mail, 22 July 2003, and "Iraq and the Responsibility to Protect", Behind the Headlines 62:1 (Toronto: Canadian Institute of International Affairs, October 2004). However, one of the Commissioners, Michael Ignatieff, now a Member of Parliament in Canada, justified the war.

14. The full list of Evans' extensive speeches and writings on R2P can be found in his book The Responsibility to Protect and on the website of the International Crisis Group: $<$ http://www.crisisgroup.org $>$. Thakur's writings encompass a wide range of products from newspaper op-eds and scholarly articles to his book The United Nations, Peace and Security. Weiss's writings are mainly academic, especially Humanitarian Intervention: Ideas in Action (Cambridge: Polity Press, 2007).

15. High-level Panel on Threats, Challenges and Change, A More Secure World: Our Shared Responsibility, UN Doc. A/59/565, December 2004, para. 201, emphasis in original.

16. Ibid., para. 207

17. Position Paper of the People's Republic of China on the United Nations Reforms, Beijing, 7 June 2005, Part III.1, "Responsibility to Protect"; available at <http://news xinhuanet. com/english/2005-06/08/content_3056817_3.htm> (accessed 30 November 2010).

18. American Interests and UN Reform: Report of the Task Force on the United Nations (Washington, DC: US Institute of Peace, 2005), p. 15.

19. Kofi A. Annan, In Larger Freedom: Towards Development, Security and Human Rights for All. Report of the Secretary-General, UN Doc. A/59/2005, 21 March 2005, paras. 122-135.

20. For an assessment, see Alex J. Bellamy, "Whither the Responsibility to Protect?", Ethics and International Affairs 20:2 (2006), pp. 143-169.

21. UN General Assembly, 2005 World Summit Outcome, UN Doc. A/RES/60/1, 24 October 2005, paras. 138-140, emphasis added; available at <http://www.un.org/summit2005/ documents html> (accessed 9 December 2010).

22. For a sceptical note on the utility of such criteria, see Alex J. Bellamy, "R2P and the Problem of Military Intervention”, International Affairs 84:4 (2008), pp. 625-630.

23. UN General Assembly, Implementing the Responsibility to Protect Report of the Secretary-General, UN Doc. A/63/677, 12 January 2009; available at <http://www.unhcr. org/refworld/docid/4989924d2.html> (accessed 10 December 2010).

24. Compare: "while the Secretary-General's focus on assistance and capacity-building has been a prudent strategy for gaining buy-in from reluctant members of international 
society, he may have paid too much deference to the opponents of R2P" (Jennifer Welsh, "Implementing the 'Responsibility to Protect'”, Policy Brief 1/2009, Oxford Institute for Ethics, Law and Armed Conflict).

25. See the discussion in the Fifth Committee of the General Assembly at its 28th meeting on 4 March 2008 (UN Doc. GA/AB/3837) in the context of the publicly announced intention of the Secretary-General to appoint Edward Luck as his special adviser with a focus on $\mathrm{R} 2 \mathrm{P}$.

26. Quoted in Evans, Responsibility to Protect, p. 4.

27. H. L. D. Mahindapala, "Peace Secretariat calls for UN Inquiry into Radhika Coomaraswamy, UN Under Secretary General, Stuck in NGO Scandal”, Lanka Times, 29 January 2008; available at <http://www.lankatimes com/fullstory.php?id=7218> (accessed 1 October 2008).

28. Klaus Naumann, John Shalikashvili, Lord Inge, Jacques Lanxade and Henk van den Breemen, Towards a Grand Strategy for an Uncertain World: Renewing Transatlantic Partnership (Lunteren, Germany: Noaber Foundation, 2007)- 30 f3204af52f6aa63fdcl6e

29. See, for example, Chris McGreal, "Demands Grow for Gaza War Crimes Investigation", ebrary Guardian, 13 January 2009; Richard Falk, "Israeli War Crimes: Why It Matters", Le Monde Diplomatique, March 2009, <http://mondediplo.com/2009/03/03warcrimes> (accessed 8 December 2010).

30. Victoria K. Holt and Tobias C. Berkman, The Impossible Mandate? Military Preparedness, the Responsibility to Protect and Modern Peace Operations (Washington, DC: Stimson Center, 2006).

31. See Jaya Murthy, "Mandating the Protection Cluster with the Responsibility to Protect: A Policy Recommendation Based on the Protection Cluster's Implementation in South Kivu, DRC", Journal of Humanitarian Assistance, 5 October 2008; available at <http:// jha.ac/2007/10/05/mandating-the-protection-cluster-with-the-responsibility-to-protect-apolicy-recommendation-based-on-the-protection-cluster $\%$ e $\% 80 \% 99$ s-implementationin-south-kivu-drc/> (accessed 30 November 2010).

32. Kofi A. Annan, "We the Peoples": The Role of the United Nations in the Twenty-first Century. Report of the Secretary-General, UN Doc. A/54/2000 (New York: United Nations, 2000), para. 216.

33. See Alan J. Kuperman, "The Moral Hazard of Humanitarian Intervention: Lessons from the Balkans", International Studies Quarterly 52:1 (2008), pp. 49-80.

34. See Ramesh Thakur, "Non-Intervention in International Relations: A Case Study", Polbitical Science 42:1 (1990), pp. 26-61l d 6e

35. See Global Centre for the Responsibility to Protect, "The Georgia-Russia Crisis and the Responsibility to Protect: Background Note", New York, 19 August 2008; available at $<$ http://www.globalr2p.org/pdf/related/GeorgiaR ussia.pdf $>$ (accessed 30 November 2010).

36. For this quote see press release of 10 October 2007, <http://www.un.org/News/Press/ docs/2007/sgsm11212.doc.htm> (accessed 8 December 2010); for other information also see the website of the Global Centre for the Responsibility to Protect at <http://www. globalr2p.org/> (accessed 1 December 2010).

37. In an interview with Roger Cohen, "How Kofi Annan Rescued Kenya", New York Review of Books, 14 August 2008, pp. 51-53, at p. 52.

38. Daily Press Briefing by the Office of the Spokesperson for the Secretary-General, 28 January 2008; available at <http://www.un.org/News/briefings/docs/2008/db080128.doc. htm (accessed 1 December 2010).

39. Desmond Tutu, "Taking the Responsibility to Protect", International Herald Tribune, 19 February 2008.

40. Thomas G. Weiss, Don Hubert, et al., The Responsibility to Protect: Research, Bibliography, Background (Ottawa: International Development Research Centre, 2001), pp. 
49-77. See also Stephen Krasner, Sovereignty: Organized Hypocrisy (Princeton, NJ: Princeton University Press 1999).

41. See World Federalist Movement, Global Consultative Roundtables on the Responsibility to Protect: Civil Society Perspectives and Recommendations for Action, Interim Report (New York: WFM, January 2009), p. 8: "At almost every roundtable, civil society emphasized how R2P principles already resonate with pre-existing cultural values."

42. I argued this in "The Responsibility to Protect Revisited", Daily Yomiuri, 12 April 2007.

43. See Ramesh Thakur, Towards a Less Imperfect State of the World: The Gulf between North and South (Berlin: Friedrich Ebert Stiftung, Dialogue on Globalization Briefing Paper 4, April 2008). The most recent manifestation of this came when the majority of the African Union, the Arab League and the Nonaligned Movement expressed reservations about the indictment by the International Criminal Court (ICC) of the President of Sudan on 4 March 2009. For an analysis of "international community" as a contested concept, see David C. Ellis “On the Possibility of 'International Community'”, International Studies Review 11:1 (2009), pp. 1-26.22 e2 e8b 7 c 30 f 3204 af 52 f6aa63 fdcl 6 e

44. See Ramesh Thakur, "Intervention, Sovereignty and the Responsibility to Protect: Ex- ebrary periences from ICISS", Security Dialogue 33:3 (2002), pp. 323-340.

45. S/PV.5577, "Security Council Open Debate on Protection of Civilians in Armed Conflict”, UN Security Council Verbatim Record, 4 December 2006, p. 8; quoted in Sarah Teitt, "Strengthening China's Role in Protecting Populations from Mass Atrocity Crimes", paper presented at the 50th annual International Studies Association Conference, New York, 15-18 February 2009, p. 9.

46. Elodie Aba and Michael Hammer, "Yes We Can? Options and Barriers to Broadening the Scope of the Responsibility to Protect to Include Cases of Economic, Social and Cultural Rights Abuse", One World Trust, Briefing Paper No. 116, London, March 2009.

47. UN General Assembly, Implementing the Responsibility to Protect, para. 67.

\section{2 e2e8b 7c30f3204af52f6aa63fdd6e} ebrary 